\title{
Von Willebrand factor in patients on mechanical circulatory support - a double-edged sword between bleeding and thrombosis
}

\author{
Bartosz Hudzik ${ }^{1}$, Jacek Kaczmarski², Jerzy Pacholewicz ${ }^{3}$, Michal Zakliczynski ${ }^{3}$, Mariusz Gasior ${ }^{1}$, \\ Marian Zembala ${ }^{3}$
}

${ }_{1}^{1}{ }^{\text {rd }}$ Department of Cardiology, SMDZ in Zabrze, Medical University of Silesia in Katowice, Silesian Centre for Heart Disease, Zabrze, Poland

${ }^{2}$ Haemostasis Laboratory, Silesian Centre for Heart Disease, Zabrze, Poland

${ }^{3}$ Department of Cardiac Surgery and Transplantology, SMDZ in Zabrze, Medical University of Silesia in Katowice, Silesian Centre for Heart Disease, Zabrze, Poland

Kardiochirurgia i Torakochirurgia Polska 2015; 12 (3): 233-237

\begin{abstract}
Mechanical circulatory support (MCS) is an umbrella term describing the various technologies used in both short- and longterm management of patients with either end-stage chronic heart failure (HF) or acute HF. Most often, MCS has emerged as a bridge to transplantation, but more recently it is also used as a destination therapy. Mechanical circulatory support includes left ventricular assist device (LVAD) or bi-ventricular assist device (Bi-VAD). Currently, 2- to 3-year survival in carefully selected patients is much better than with medical therapy. However, MCS therapy is hampered by sometimes life-threatening complications including bleeding and device thrombosis. Von Willebrand factor (VWF) has two major functions in haemostasis. First, it plays a crucial role in platelet-subendothelium adhesion and platelet-platelet interactions (aggregation). Second, it is the carrier of factor VIII (FVIII) in plasma. Von Willebrand factor prolongs FVIII half-time by protecting it from proteolytic degradation. It delivers FVIII to the site of vascular injury thus enhancing haemostatic process. On one hand, high plasma levels of VWF have been associated with an increased risk of thrombosis. On the other, defects or deficiencies of VWF underlie the inherited von Willebrand disease or acquired von Willebrand syndrome. Here we review the pathophysiology of thrombosis and bleeding associated with vWF.
\end{abstract}

Key words: von Willebrand factor, mechanical circulatory support, bleeding, thrombosis.

\section{Introduction}

Mechanical circulatory support (MCS) is an umbrella term describing various technologies used in both shortand long-term management of patients with either end-

\section{Streszczenie}

Mechaniczne wspomaganie krążenia (mechanical circulatory support - MCS) jest ogólnym terminem określającym różne technologie stosowane w zarówno krótko-, jak i długoterminowym postępowaniu z pacjentami ze schyłkową przewlekłą niewydolnością serca lub ostrą niewydolnością serca. Najczęściej mechaniczne wspomaganie serca stosowano jako pomost do przeszczepu, ale w ostatnim czasie używa się go również jako terapii docelowej. Obecnie wskaźniki 2- do 3-letnich przeżyć u dokładnie wyselekcjonowanych pacjentów są lepsze niż w przypadku innego typu terapii. Niemniej, leczenie za pomocą MSC bywa niekiedy obciążone zagrażającymi życiu komplikacjami, takimi jak krwawienie czy zakrzepica urządzenia. Czynnik von Willebranda (von Willebrand factor - vWF) pełni dwie ważne funkcje związane z hemostazą. Odgrywa on kluczową rolę $w$ agregacji płytek krwi i jest nośnikiem czynnika VIII (factor VIII - FVIII) w osoczu. Czynnik von Willebranda przedłuża też okres półtrwania FVIII, chroniąc go przed degradacją proteolityczną. Duże stężenia vWF w osoczu powiązano ze zwiększonym ryzykiem zakrzepicy. Zaburzenia lub niedobór vWF leżą u podstaw dziedzicznej choroby von Willebranda i nabytego zespołu von Willebranda.

Słowa kluczowe: vWF, mechaniczne wspomaganie krążenia, krwawienie, zakrzepica.

stage chronic heart failure (HF) or acute HF. Most often, MCS has emerged as a bridge to transplantation, but more recently it is also used as a destination therapy. Mechanical circulatory support includes left ventricular assist device (LVAD) or bi-ventricular assist device (Bi-VAD) [1].

Address for correspondence: Bartosz Hudzik, MD, PhD, Third Department of Cardiology, Silesian Centre for Heart Disease,

9 Curie-Sklodowska St., 41-800 Zabrze, Poland, phone: +48 32 3733619, fax: +48 32 2732679, e-mail: bartekh@mp.pl 
Currently, two- to three-year survival in carefully selected patientsis much better than with medical therapy. However, MCS therapy is hampered by sometimes lifethreatening complications including bleeding and device thrombosis [1].

\section{Left ventricular assist deviceand bleeding}

Bleeding, especially from the gastro-intestinal (Gl) tract, has recently been identified as one of the most common adverse events of LVAD treatment and is a major cause of morbidity [2]. However, there has been no evidence that such bleeding events increase mortality. The most commonly reported sources of bleeding are epistaxis, Gl bleeding, bleeding of the mediastinum and thorax, and intracranial haemorrhage. The incidence of bleeding, depending on its definition, varies widely between $10 \%$ and $50 \%$ with no difference in the overall bleeding rates between axial- and pulsatile-flow devices [2]. Notwithstanding, an increased risk of GI bleeding has been linked to axial-flow devices. Following concerns that LVAD may predispose patients to thromboembolic episodes, recommendations have been made that all patients on LVAD be treated with antithrombotic therapy (anticoagulant and antiplatelet agent). Consequently, much of the bleeding risk is attributed to the antithrombotic regimen. However, there are reports that the observed increased risk of bleeding is higher than would be anticipated from antithrombotic therapy alone [3]. The reported rates of GI and intracranial haemorrhages are high $(30 \%$ and $11 \%$, respectively) [4]. So, in fact, the risk of bleeding complications is substantially higher than that of thromboembolic complications. The mechanisms associated with this phenomenon are not yet fully understood. Nonetheless, colonic angiodysplasia, impaired platelet aggregation, and acquired von Willebrand syndrome are implicated in that process [2].

\section{Left ventricular assist device and thrombosis}

Left ventricular assist device thrombosis occurs in $2-13 \%$ of adult patients with a continuous-flow LVAD (axial-flow 4-13\%, centrifugal-flow 2\%) [5]. Thrombus may be formed in various sites, i.e. left ventricle, inflow cannula, pump housing, outflow cannula, outflow graft, or the aortic root, thus leading to serious cardiovascular events including among others: thromboembolic stroke, peripheral thromboembolism, LVAD malfunction with reduced systemic flows or life-threatening haemodynamic impairment, cardiogenic shock, and even death [5]. Many therapeutic approaches have been employed in LVAD thrombosis management. These strategies include surgical procedures (device exchange, catheter-based thrombectomy) $[6,7]$ and medical therapy. The latter may consist of: thrombolytic therapy with recombinant tissue plasminogen activator (intravenous or intraventricular), intensified anticoagulation treatment with unfractionated heparin, or bivalirudin, intensified antiplatelet treatment with intravenous GP Ilb/ Illa inhibitors (eptifibatide, tirofiban) or with thienopyri- dine-derivative P2Y12 ADP receptor inhibitor (clopidogrel). However, management guidelines have not been established and are awaited impatiently.

\section{Von Willebrand factor}

Von Willebrand factor (vWF)is an adhesive glycoprotein, circulating in plasma in a concentration of $5-10 \mu \mathrm{g} / \mathrm{ml}$. It is synthesised in the endothelial cells and megakaryocytes. The gene encoding VWF is located at the short arm of human chromosome 12(12p13.2). The mature molecule contains 2050 aminoacids. Von Willebrand factor is secreted from the cell along a constitutive and a regulated pathway. It circulates in plasma in the form of multimers comprising various numbers of monomers. The largest vWF multimers display enhanced thrombogenic functions, possibly because multiple interactive sites for vessel wall components and platelets support more efficient adhesion [8]. Physiological reduction in size of the multimers occurs through a controlled proteolytic cleavage by metalloproteinase ADAMTS13. This cleavage affects the size of circulating multimers and consequently modulates proadhesive functions [8].

Von Willebrand factor has two major functions in haemostasis. First, it plays a crucial role in platelet-subendothelium adhesion and platelet-platelet interactions (aggregation). Second, it is the carrier of factor VIII (FVIII) in plasma. Von Willebrand factor prolongs FVIII half-time by protecting it from proteolytic degradation. It delivers FVIII to the site of vascular injury thus enhancing haemostatic process [9]. One vWF monomer can bind one FVIII molecule; however, in vivo only $1-2 \%$ of VWF monomers are occupied by FVIII [9].

On one hand, high plasma levels of VWF have been associated with an increased risk of thrombosis [10]. On the other, defects or deficiencies of VWF underlie the inherited von Willebrand disease (vWD) or acquired von Willebrand syndrome (vWS) [9]. Von Willebrand disease comprises two major categories of conditions:

1. Quantitative VWF deficiency:

- type 1 - partial quantitative deficiency of VWF (60$70 \%$ of patients),

- type 3 - virtually complete deficiency of vWF (5-10\% of patients).

2. Qualitative vWF deficiency:

- type 2 - qualitative deficiency of VWF (10-30\% of patients):

- type 2A - decreased platelet-dependent function associated with the absence of high-molecular-weight vWF multimers,

- type $2 \mathrm{~B}$ - increased affinity for platelet GPIb,

- type $2 \mathrm{M}$ - decreased platelet-dependent function not caused by the absence of high-molecular-weight VWF multimers,

- type $2 \mathrm{~N}$ - markedly decreased affinity for factor VIII.

About $60 \%$ of the variation in VWF plasma is due to genetic factors, with the $\mathrm{ABO}$ group accounting for only about $30 \%$ [9, 11]. Additionally, many acquired conditions, either physiologic (stress, pregnancy) or pathologic (inflammation - vWF acts as an acute phase reactant), can induce 
fluctuations in vWF concentrations [9, 12]. Early onset of bleeding, previous bleeding events, positive family history, the absence of precipitating factor, and good response to vWF concentrate are usually suggestive of inherited von Willebrand disease. Whereas, late onset of bleeding, no prior bleeding events, negative family history, the presence of precipitating condition, and usually transient or no response to standard therapy indicate acquired von Willebrand syndrome.

\section{Von Willebrand factor - diagnostic aspects}

Given the complexity of VWF pathophysiology, there is no single 'robust' assay that can be used in the diagnosis of bleeding or thrombotic entities. Generally, the diagnosis warrants performing several tests. These can be divided in two large groups: screening tests and discriminating assays [12]. A complete set of laboratory investigations, including bleeding time, PFA-100 closure times, FVIII coagulant activity (FVIII:C), vWF ristocetin cofactor (vWF:RCo), vWF collagen binding (VWF:CB), VWF antigen (VWF:Ag) and vWF propeptide ( $v W F p p)$, ristocetin-induced platelet aggregation (RIPA), multimeric analysis of VWF (gel electrophoresis), and the response of FVIII:C and VWF parameters to desmopressin (DDAVP), is necessary to fully diagnose all variants of VWD and to discriminate between the types [13]. Diagnostic algorithms in congenital and acquired forms of the disease are similar. The diagnostic process starts with basic evaluation (screening tests), which is then followed by specialist tests [12].

Screening tests are usually performed in patients with a tendency to bleed. Bleeding time (BT) is usually prolonged, but it may be within normal range in mild cases of vWD. Closure time (CT) using PFA-100 (Platelet Function Analyzer) is typically prolonged and has been reported to be superior to BT. Prothrombin time (PT) is normal. Whereas prolongation of partial thromboplastin time (PTT) depends on varying plasma FVIII levels. Clinical suspicion of VWD/ vWS together with abnormal screening tests requires application of specific tests: FVIII:C, vWF:RCo, vWF:CB, vWF:Ag, vWFpp, RIPA, and gel electrophoresis (Table I) [12].

\section{Von Willebrand factor, left ventricular assist device, and bleeding}

Angiodysplasia denotes submucosal vascular abnormality commonly found throughout the Gl tract. This finding is especially common among the elderly. There are several pathomechanisms suggested for the formation of angiodysplasia. These include:

- increased intraluminal pressures and vascular smooth muscle contraction lead to increased sympathetic tone and smooth muscle relaxation. This, in turn, results in atrioventricular dilation and ensuing angiodysplasia formation;

- LVAD-associated chronic low pulse pressure leads to local hypoperfusion with subsequent hypoxia, vascular dilation, and finally angiodysplasia.

High molecular weight multimers (HMWM) of vWF are essential for maintaining haemostasis. High molecular weight multimers homeostasis is regulated mainly by metalloproteinase ADAMTS13. High shear stress induced by LVAD results in a conformational change of the VWF HMWM predisposing the multimers to proteolytic cleavage by ADAMTS13. All of these processes lead to the develop-

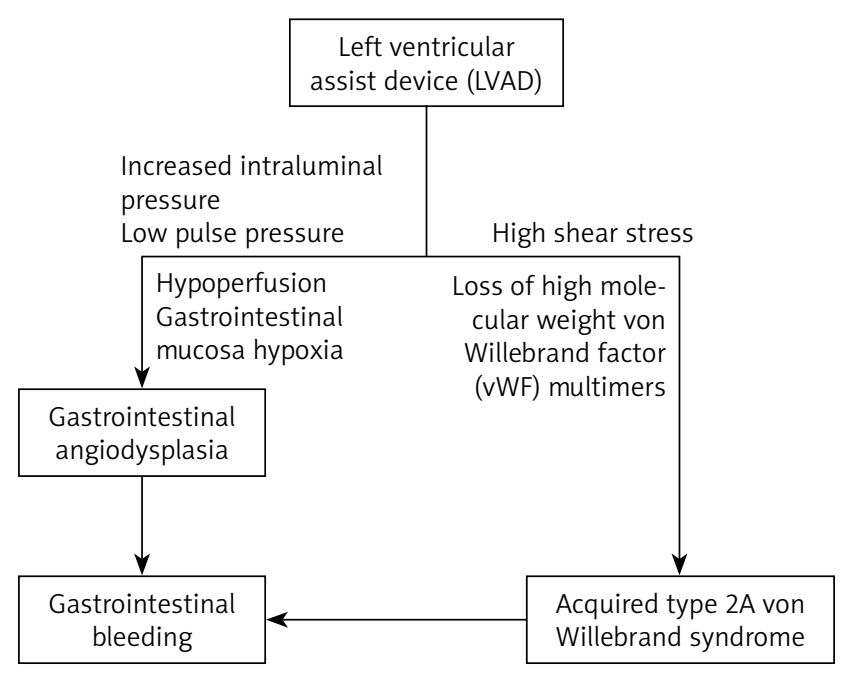

Fig. 1. Pathophysiology of bleeding events in patients on mechanical circulatory support

Tab. I. Specific tests used in the classification of VWD type [23]

\begin{tabular}{lccccccc} 
vWD type & vWF:Ag & vWF:RCo & $\begin{array}{c}\text { vWF:RCol } \\
\text { vWF:Ag ratio }\end{array}$ & FVIII:C & vWFmultimer & $\begin{array}{c}\text { vWF:CB } \\
\text { vWF:CB/ } \\
\text { vWF:Ag ratio }\end{array}$ \\
$\begin{array}{l}\text { Normal } \\
\text { values }\end{array}$ & $50-150 \mathrm{IU} / \mathrm{dl}$ & $50-150 \mathrm{IU} / \mathrm{dl}$ & $\sim 1.0$ & $50-150 \mathrm{IU} / \mathrm{dl}$ & Normal pattern & $50-200 \mathrm{IU} / \mathrm{dl}$ & $\sim 1.0$ \\
\hline 1 & $\downarrow$ & $\downarrow$ & $\mathrm{N}$ & $\mathrm{N} / \downarrow$ & $\mathrm{N}$ & $\downarrow$ & $\mathrm{N}$ \\
\hline 3 & $\downarrow \downarrow \downarrow$ & $\mathrm{A}$ & - & $\downarrow \downarrow \downarrow$ & $\mathrm{A}$ & $\mathrm{A}$ & - \\
\hline $2 \mathrm{~A}$ & $\downarrow$ & $\downarrow \downarrow \downarrow$ & $<0.6-0.7$ & $\mathrm{~N} / \downarrow$ & $\downarrow \downarrow$ HMWM & $\downarrow \downarrow \downarrow$ & $<0.6-0.7$ \\
\hline $2 \mathrm{~B}$ & $\downarrow$ & $\downarrow \downarrow \downarrow$ & $<0.6-0.7$ & $\mathrm{~N} / \downarrow$ & $\downarrow$ HMWM & $\downarrow \downarrow \downarrow$ & $<0.6-0.7$ \\
\hline $2 \mathrm{M}$ & $\mathrm{N} / \downarrow$ & $\downarrow$ & $<0.6-0.7$ & $\mathrm{~N} / \downarrow$ & $\mathrm{N}$ & $\mathrm{N} / \downarrow$ & $\mathrm{N} / \downarrow$ \\
\hline $2 \mathrm{~N}$ & $\mathrm{~N} / \downarrow$ & $\mathrm{N} / \downarrow$ & $\mathrm{N}$ & $\downarrow \downarrow \downarrow$ & $\mathrm{N}$ & $\mathrm{N} / \downarrow$ & $\mathrm{N}$ \\
\hline
\end{tabular}

vWD - von Willebrand disease, vWF - von Willebrand factor, vWF:Ag - vWF antigen, vWF:RCo - vWFristocetin cofactor, FVIII:C - FVIII coagulant activity, vWF:CB vWF collagen binding,

$\mathrm{N}$ - normal, A - absent, $\downarrow$ - low, $\downarrow \downarrow \downarrow$ - very low, HMWM - high-molecular-weight multimers 
ment of acquired von Willebrand syndrome 2A (vWS2A). Both, retrospective and prospective studies, report that LVAD implantation leads to substantial reductions in HMWM of VWF $[14,15]$. The triad: angiodysplasia, aVS2A, and GI bleeding (Fig. 1) share a striking resemblance with Heyde's syndrome. This condition comprises aortic stenosis, angiodysplasia, vWS2A, and bleeding. The sensitivity of various laboratory tests for VWS2A in patients with bleeding Gl dysplasia is as follows: gel electrophoresis (quantification of $\mathrm{HMWM}$ ) > PFA-100 closure time $>$ vWF:RCo > bleeding time > vWF:Ag [16]. Since LVAD explantation is rarely an option, treatment modalities of bleeding Gl dysplasia include: endoscopic laser photocoagulation, oestrogen/progestin therapy (structural changes in blood vessels), and somatostatin or octreotide therapy. Unfortunately, there is little experience in using desmopressin or FVIII:VWF concentrates in vWS2A associated with cardiovascular disease [16]. Due to end-stage heart failure requiring MCS, surgical bowel resection does not present as a feasible option. Some authors suggest the use of recombinant factor VIla, a panhaemostatic agent) in acute haemorrhages [17]. However, its use is associated with an enhanced risk of thrombotic events.

\section{Von Willebrand factor, left ventricular assist device, and thrombosis}

Essential prothrombotic vWF properties include binding and transportation of procoagulant FVIII, mediating platelet adhesion and aggregation, and propagating thrombus growth [8].

Epidemiological studies provide some evidence that high vWF levels are associated with a moderately increased risk of arterial thrombosis [18]. However, there are reports that patients with severe VWD are not protected against atherosclerosis [19]. Thus, it is implied that vWF does not play a role in the atherosclerotic process, but only in occlusive arterial thrombosis [18].

In the Stroke Prevention and Atrial Fibrillation III trial, the risk of thromboembolic stroke, myocardial infarction, and death increased 1.2-fold for each $20 \mathrm{U} / \mathrm{dl}$ increment in VWF [20].

The odds ratio for venous thrombosis in patients with vWF levels above $150 \mathrm{U} / \mathrm{dl}$ compared to those with levels lower than $100 \mathrm{U} / \mathrm{dl}$ was $3.0(95 \% \mathrm{Cl}: 1.8-4.9)$ in the univariate analysis. However the results were rendered insignificant after adjusting for blood group and FVIII in the multivariate analysis - odds ratio 1.2 (95\% Cl: 0.6-2.1), suggesting that the effect of VWF on the risk of venous thrombosis was fully explained by FVIII levels [18, 21]. A large, prospective population-based study suggested that vWF made a significant contribution to the risk of venous thrombosis, independently of FVIII [22]. The hazard ratios of venous thromboembolism were 4.6 for the highest quartile and 7.6 for the highest quintile of vWF. Finally, given vWF is a carrier for FVIII, it could propagate its prothrombotic actions through FVIII.

Pathological arterial blood flow generates fluid shear stresses. At shear rates greater than $10,000 \mathrm{~s}^{-1}$, often present in LVAD devices, activation-independent platelet aggregation mediated by soluble VWF facilitates adhesion and precedes stable aggregation [8]. Therefore, VWF is absolutely essential in thrombus formation, haemostasis, and LVAD thrombosis.

\section{Our experience}

Twelve patients with end-stage heart failure on LVAD were followed for four weeks (four blood samples for each patient). Every week extended haemostasis panel was assessed, including vWF activity, factor VIII activity, fibrinogen level, D-dimer level, platelet response to arachidonic acid (ASPI test) and adenosine diphosphate (ADP test), thrombin receptor activating peptide- 6 (TRAP test), and collagen (COL test). Time-dependant changes of haemostatic parameters are listed in Table II. There were significant variations in VWF and factor VIII activity. Despite constant antiplatelet therapy, there were significant changes in platelet function tests (ASPI < ADP < COL test, TRAP test) over time. D-dimer and fibrinogen levels were constant during the study period. There were strong, positive correlations between vWF and factor VIII, and VWF and D-dimer. There were no thrombotic or haemorrhagic events during the study. Mechanical circulatory support in patients with end-stage heart failure is linked to substantial variations of haemostatic parameters that could create a prothrombotic milieu and, thus, lead to LVAD thrombosis.

Tab. II. Haemostatic parameters in studied patients

\begin{tabular}{|c|c|c|c|c|c|c|c|c|}
\hline & $\begin{array}{c}\text { D-dimer } \\
(n<0.5) \\
{[\mathrm{mg} / \mathrm{l}]}\end{array}$ & $\begin{array}{c}\text { Fibrinogen } \\
(n<400) \\
{[\mathrm{mg} / \mathrm{dl}]}\end{array}$ & $\begin{array}{c}\text { ASPI } \\
(n>695) \\
\text { Aggregation } \\
\text { units }\end{array}$ & $\begin{array}{c}\text { ADP } \\
(n>590) \\
\text { Aggregation } \\
\text { units }\end{array}$ & $\begin{array}{c}\text { Factor VIII } \\
(n<150) \\
\text { IU/dl }\end{array}$ & $\begin{array}{c}\text { VWF } \\
(n<150) \\
\text { IU/dl }\end{array}$ & $\begin{array}{l}\text { COL test } \\
(n>708)\end{array}$ & $\begin{array}{l}\text { TRAP test } \\
(n>920)\end{array}$ \\
\hline Week 1 & $\begin{array}{c}3.9 \\
(3.1-10.1) \\
\end{array}$ & $\begin{array}{c}644 \\
(601-676) \\
\end{array}$ & $\begin{array}{c}389 \\
(171-1230)\end{array}$ & $\begin{array}{c}169 \\
(85-1476)\end{array}$ & $\begin{array}{c}281 \\
(202-597) \\
\end{array}$ & $\begin{array}{c}291 \\
(198-316) \\
\end{array}$ & $\begin{array}{c}194 \\
(166-749)\end{array}$ & $\begin{array}{c}320 \\
(292-1592)\end{array}$ \\
\hline Week 2 & $\begin{array}{c}5.1 \\
(3.3-8.0) \\
\end{array}$ & $\begin{array}{c}702 \\
(516-842) \\
\end{array}$ & $\begin{array}{c}780 \\
(530-1382)\end{array}$ & $\begin{array}{c}266 \\
(238-376) \\
\end{array}$ & $\begin{array}{c}199 \\
(133-367) \\
\end{array}$ & $\begin{array}{c}198 \\
(156-231)\end{array}$ & $\begin{array}{c}618 \\
(255-924) \\
\end{array}$ & $\begin{array}{c}506 \\
(432-1398) \\
\end{array}$ \\
\hline Week 3 & $\begin{array}{c}3.6 \\
(3.4-11.5) \\
\end{array}$ & $\begin{array}{c}688 \\
(622-720) \\
\end{array}$ & $\begin{array}{c}506 \\
(201-638) \\
\end{array}$ & $\begin{array}{c}629 \\
(509-787) \\
\end{array}$ & $\begin{array}{c}200 \\
(127-281) \\
\end{array}$ & $\begin{array}{c}167 \\
(101-281) \\
\end{array}$ & $\begin{array}{c}266 \\
(197-365) \\
\end{array}$ & $\begin{array}{c}831 \\
(700-1464) \\
\end{array}$ \\
\hline Week 4 & $\begin{array}{c}3.8 \\
(3.6-4.9)\end{array}$ & $\begin{array}{c}642 \\
(510-694)\end{array}$ & $\begin{array}{c}470 \\
(201-523)\end{array}$ & $\begin{array}{c}495 \\
(395-569)\end{array}$ & $\begin{array}{c}167 \\
(127-246)\end{array}$ & $\begin{array}{c}213 \\
(134-260)\end{array}$ & $\begin{array}{c}248 \\
(197-352)\end{array}$ & $\begin{array}{c}901 \\
(814-1200)\end{array}$ \\
\hline$p$ & 0.4 & 0.3 & 0.006 & 0.003 & 0.00003 & 0.01 & 0.01 & 0.01 \\
\hline
\end{tabular}




\section{Funding}

The creation of the paper was supported by a grant from the Medical University of Silesia (No. KNW-1-161/N/3/0).

\section{Disclosure}

Authors report no conflict of interest.

\section{References}

1. McMurray JJ, Adamopoulos S, Anker SD, Auricchio A, Böhm M, Dickstein K, Falk V, Filippatos G, Fonseca C, Gomez-Sanchez MA, Jaarsma T, Køber L, Lip GY, Maggioni AP, Parkhomenko A, Pieske BM, Popescu BA, Rønnevik PK, Rutten FH, Schwitter J, Seferovic P, Stepinska J, Trindade PT, Voors AA, Zannad F, Zeiher A;ESC Committee for Practice Guidelines.ESC Guidelines for the diagnosis and treatment of acute and chronic heart failure 2012: The Task Force for the Diagnosis and Treatment of Acute and Chronic Heart Failure 2012 of the European Society of Cardiology. Developed in collaboration with the Heart Failure Association (HFA) of the ESC. Eur Heart J 2012; 33: $1787-1847$.

2. Suarez J, Patel CB, Felker GM, Becker R, Hernandez AF, Rogers JG. Mechanisms of bleeding and approach to patients with axial-flow left ventricular assist devices. Circ Heart Fail 2011; 4: 779-784.

3. Crow S, John R, Boyle A, Shumway S, Liao K, Colvin-Adams M, Toninato C, Missov E, Pritzker M, Martin C, Garry D, Thomas W, Joyce L. Gastrointestinal bleeding rates in recipients of nonpulsatile and pulsatile left ventricular assist devices. J Thorac Cardiovasc Surg 2009; 137: 208-215.

4. Slaughter MS, Rogers JG, Milano CA, Russell SD, Conte JV, Feldman D, Sun B, Tatooles AJ, Delgado RM, 3rd, Long JW, Wozniak TC, Ghumman W, Farrar DJ, Frazier $\mathrm{OH}$. Advanced heart failure treated with continuous-flow left ventricular assist device. N Engl J Med 2009; 361: 2241-2251.

5. Bartoli CR, Ailawadi G, Kern JA. Diagnosis, nonsurgical management, and prevention of LVAD thrombosis. J Card Surg 2014; 29: 83-94.

6. Stulak JM, Cowger J, Haft JW, Romano MA, Aaronson KD, Pagani FD. Device exchange after primary left ventricular assist device implantation: indications and outcomes. Ann Thorac Surg 2013; 95: 1262-1267; discussion $1267-$ 1268.

7. Barbieri A, Bertelli L, Sangiorgi GM. Novel application of Angiojetrheolyticthrombectomy for massive thrombosis of the native aortic valve and Jarvick 2000 ventricular assist device in a patient with end-stage heart failure. Catheter Cardiovasc Interv 2011; 78: 958-961.

8. Ruggeri ZM. The role of von Willebrand factor in thrombus formation. Thromb Res 2007; 120 Suppl 1: S5-S9.

9. Castaman G, Federici AB, Rodeghiero F, Mannucci PM. Von Willebrand's disease in the year 2003: towards the complete identification of gene defects for correct diagnosis and treatment. Haematologica 2003;88:94-108.
10. Franchini M, Lippi G. Von Willebrand factor and thrombosis. Ann Hematol 2006; 85: 415-423.

11. Orstavik KH, Magnus P, Reisner H, Berg K, Graham JB, Nance W. Factor VIII and factor $\mathrm{IX}$ in a twin population. Evidence for a major effect of $\mathrm{ABO}$ locus on factor VIII level. Am J Hum Genet 1985; 37: 89-101.

12. Flood VH. Perils, problems, and progress in laboratory diagnosis of von Willebrand disease. Semin Thromb Hemost 2014; 40: 41-48.

13. Gadisseur A, Hermans C, Berneman Z, Schroyens W, Deckmyn H, Michiels JJ. Laboratory diagnosis and molecular classification of von Willebrand disease. Acta Haematol 2009; 121: 71-84.

14. Uriel N, Pak SW, Jorde UP, Jude B, Susen S, Vincentelli A, Ennezat PV, Cappleman S, Naka Y, Mancini D. Acquired von Willebrand syndrome after continuous-flow mechanical device support contributes to a high prevalence of bleeding during long-term support and the time of transplantation. J Am Coll Cardiol 2010; 56: 1207-1213.

15. Crow S, Chen D, Milano C, Thomas W, Joyce L, Piacentino V, 3rd, Sharma R, Wu J, Arepally G, Bowles D, Rogers J, Villamizar-Ortiz N. Acquired von Willebrand syndrome in continuous-flow ventricular assist device recipients. Ann Thorac Surg 2010; 90: 1263-1269; discussion 1269.

16. Warkentin TE, Moore JC, Anand SS, Lonn EM, Morgan DG. Gastrointestinal bleeding, angiodysplasia, cardiovascular disease, and acquired von Willebrand syndrome. Transfus Med Rev 2003; 17: 272-286.

17. Meijer K, Peters FT, van der Meer J. Recurrent severe bleeding from gastrointestinal angiodysplasia in a patient with von Willebrand's disease, controlled with recombinant factor VIIa. Blood Coagul Fibrinolysis 2001; 12: 211-213.

18. Franchini M, Lippi G. The role of von Willebrand factor in hemorrhagic and thrombotic disorders. Crit Rev Clin Lab Sci 2007; 44: 115-149.

19. Sramek A, Bucciarelli P, Federici AB, Mannucci PM, De Rosa V, Castaman G, Morfini M, Mazzucconi MG, Rocino A, Schiavoni M, Scaraggi FA, Reiber JH, Rosendaal FR. Patients with type 3 severe von Willebrand disease are not protected against atherosclerosis: results from a multicenter study in 47 patients. Circulation 2004; 109: 740-744.

20. Conway DS, Pearce LA, Chin BS, Hart RG, Lip GY. Prognostic value of plasma von Willebrand factor and soluble P-selectin as indices of endothelial damage and platelet activation in 994 patients with nonvalvular atrial fibrillation. Circulation 2003; 107: 3141-3145.

21. Koster T, Blann AD, Briet E, Vandenbroucke JP, Rosendaal FR. Role of clotting factor VIII in effect of von Willebrand factor on occurrence of deep-vein thrombosis. Lancet 1995; 345: 152-155.

22. Tsai AW, Cushman M, Rosamond WD, Heckbert SR, Tracy RP, Aleksic N, Folsom AR. Coagulation factors, inflammation markers, and venous thromboembolism: the longitudinal investigation of thromboembolism etiology (LITE). Am J Med 2002; 113: 636-642.

23. http://practical-haemostasis.com/Factor\%20Assays/VWF/vwf_assays_introduction.html (accessed on March 04, 2015) 